\title{
Correction to: Impact of Reaction Chamber Geometry on the Particle-Residence-Time in Flame Spray Process
}

\author{
Lizoel Buss $^{1}$ (D) $\cdot$ Dirceu Noriler $^{2}$ (D) $\cdot$ Udo Fritsching $^{1,3}$ (D) \\ Published online: 15 September 2021 \\ (c) Springer Nature B.V. 2021
}

\section{Correction to: Flow, Turbulence and Combustion https://doi.org/10.1007/s10494-020-00187-1}

Open Access This article is licensed under a Creative Commons Attribution 4.0 International License, which permits use, sharing, adaptation, distribution and reproduction in any medium or format, as long as you give appropriate credit to the original author(s) and the source, provide a link to the Creative Commons licence, and indicate if changes were made.

The images or other third party material in this article are included in the article's Creative Commons licence, unless indicated otherwise in a credit line to the material. If material is not included in the article's Creative Commons licence and your intended use is not permitted by statutory regulation or exceeds the permitted use, you will need to obtain permission directly from the copyright holder.

To view a copy of this licence, visit http://creativecommons.org/licenses/by/4.0/.

Publisher's Note Springer Nature remains neutral with regard to jurisdictional claims in published maps and institutional affiliations.

The original article can be found online at https://doi.org/10.1007/s10494-020-00187-1.

Lizoel Buss

1.buss@iwt.uni

1 Chemical and Process Engineering, Leibniz Institute for Materials Engineering IWT, Bremen, Germany

2 School of Chemical Engineering, University of Campinas, Campinas, Brazil

3 Particles and Process Engineering, University of Bremen, Bremen, Germany 